\author{
Maryna Vilkova \\ Oles Honchar Dnipropetrovsk National University, Ukraine
}

\title{
PECULIARITIES OF COMPARATIVE ANALYSIS OF E.SENON-THOMPSON'S SHORT-STORY «ARNAUX, THE CHRONICLE OF A HOUSING PIGEON» AND ITS RUSSIAN TRANSLATION BY M. CHUKOVSKY
}

\begin{abstract}
The article is devoted to structural, lexical and stylistic peculiarities as well as national EnglishCanadian peculiarities of E.Seton-Thompson's animal short-story «Arnaux, the chronicle of a Housing Pigeon» and its translation into Russian by M.K.Chukovsky. The main devices which the translator uses are scrutinized.
\end{abstract}

Key words: animal short-story, comparative analysis, translation technique, transformation.

The method of comparative analysis is important for the development of sense of the presentation consequence, the skill to see the structures of the original text and national language, to express the content with the help of these structures. Comparative analysis of the original and the function text translation is a varied phenomenon. Almost every scholar working in the given field offers his own style. But only in their interaction these methods will help to analyze the fiction text translation in detail.

Translation as a text creativity is characterized by its being the second which defines its essence. Translation as secondary creativity eliminates a translator the necessity to solve true literary problems, increasing responsibility for the «recreation» of the original text in another cultural background. Due to this we have the problem of the investigation method which would respond to translational cultural paradigm which implies crossing the border of the textual material as the translator should study historical conditions of translation creation, to realize the translator's tasks, to find out positive and negative sides of the method and creative individuality, to define the reflection of the latter in the translation and to estimate the quality of the translation» (Gachechiladze, 1965, 246).

The aim of the comparative analysis of the primary text and translation is defined as the setting of a correspondence degree of the translated text to the original 
one. But the question of "starting point" of the functional correspondence setting which can be an author as well as a recipient is still under the debates: the translation fulfill the original function as it is given by the author or as it was seen by the reader? (Rebri, 2012, 239).

V. V. Vinogradov percepts the author's image as the main and multimeaningful stylistic characteristic of separate literary work as well as all the fictional literature. The image of the author is firstly taken in its stylistic individualization, in its lingvo-fictional embodiment — through the choice and realization of definite speech-speaking innovations is still given to the text.

In the context of translation investigations contradiction between the author and reader of the original text reflect the correlation between the translator and reader as the translator is not only a reader and an interpreter of the original creative work, but also the author of the translator's text. Reading is a co-creative step of the literary talent. That is why, on the one hand, in the translation of the original text the author's idea takes place but, on the other hand, it is reflected only in the way it is felt and reflected by the translator.

A specificity of the translator as a creative object is his representation of a certain «creolization» of the author's poetics with his own one. Thus, in the texts of the translation along with author's strategy consciously or subconsciously the translator's strategy is reflected.

Intense development of the translation literature and compared literary studies since the end of XIX-XX centuries caused a great stream of interest in theoretical and methodological problems of this specific intercultural relations.

A number of foreign and home men's of literature publications are devoted to the complex lingvoartistic analysis of the literary text (Gachecheladze G, Kashkin I., Koptilov V., Popovich O., Alekseev S., Gurova Yu., Maslennikova E., Nekriach T., Skygarevska O.). But the complexity of the problem lies in the necessity to take into account many relevant features that define creative value and the whole of the translation, doesn't give it a chance to lose its actuality.

Comparative analysis gives a chance to find an obvious analogy of the approaches to lingvofictional analysis of the original as well as translation text, which is demonstrated in the use of methodological principals of hierarchy, levelness, coordination, intercorrelation/interdependence/interinflue nce.

Understanding the complexity of textcentric conception of creativity in the translation, one may speak about its peculiarity - integrity which is connected with the translator's ability to combine the peculiarities of many different formalcontextual «fields» of literary work in the organic way. Investigator G.Gachechiladze 
underlines the definition of the literary work as the integrity of creation A guarantee of the full value translation success becomes the translator's ability to find «stylistic key» to the text, as the translator analyses the author's creativity,

V. Koptilov defines organic mixture of speaking and literary parts of the analysis as «partners». Objectivity of the translation analysis can be reached only due to the equal attitude to two main parts of a literary text - idea-image and speech-stylistic ones that gives a scholar a possibility to form his classical definition of artistic translation as a «process in which translation text preserves its idea-image structure of the original and works as its semantic-stylistic parallel» (Koptilov, 1972, 183). V. Koptilov points out the necessity to feel the interconnection between the content and form, the borders in which it is possible to change the form in order not to ruin the content»(Koptilov, 1972, 91). This point of view is supported by M. Novikova, who believes that often "it is necessary to change the content of the original in some way: the author himself varies and changes it, going deep to the core. In is impossible to ruin the content» (Novikova, 1982, 42). Thus, conceptions of the change of the first original text on the language level are necessary to preserve its content and do not disturb creative interconnection of the author's and translator's image.

Canadian literature today is one of the key objects for study by many contemporary investigators. One of the main tasks for them is to try to understand national sources, the way of development and formation of original literary works peculiarities of Canadian writers. The attention of a specialist in the study of literature who studies the Canadian literature genre specificity is especially paid to specific genres which make Canadian literature prominent on the background of the other national cultures. First of all, it concerns the genre of an animal short-story, which became one of the most popular in the literature of Canada at the end of the XIXth century. Canadian literature investigators $(\mathrm{N}$. Ovcharenko, $\mathrm{O}$. Gokysheva, V.New, T.Maclulich, M.Atwood) are sure that this «animal story» stands at the sources of national Canadian literature, reflecting important moments in the national Canadian literature self-consciousness (Sukhenko, 2002, 107). According to the Canadian scholar G.Woodcock, there are some vivid differences between English, American and Canadian animal story. The characters of English animal story are people in the image of animals, who have peculiar habits of the behaviour. In American story people, on the contrary, oppose animals that are the symbols of civilization that brings their death. Canadian animal stories are devoted to animals, in which they as well as people are demonstrated as the victims of the unknown land, their habitat. Among 
Canadian animal-story writers Ernest SetonThompson, Ch. D. Roberts should be mentioned.

One of the central topics in EnglishCanadian literature is a topic of nature as an integral part of North American region reality (Hammill, 2007, 4). Since the time of the first attempts to explore Canada there has been a necessity to learn unknown world of the North that gave the feeling of fear and mistrust to the nature. At the end of the XIX century it became a subject for a detailed scrutinizing. Explorer B. Methews separates peculiarities of Canadian «short story»: compression, emotional satiety, unity of the topic, personages' duality, logical narration, fantasy element that got a new impulse of functioning which is connected with a peculiar topicality and problems (The Canadian Imagination..., 1977, 284).

The narration about nature shows a certain mixture of European, Indian, American features which demonstrates the uniqueness of Canadian national world perception, show the specificity of Canadian national character in peculiar forms of artistic embodiment at the stage of Canadian sociocultural development at the end of the XIX century (Korotich, 1980, 217).

English-Canadian stories about nature introduced Canadian topicality in the world literature but at the same time to immortalize specific vision of Canada as a country of miracle primary northern landscapes with their mythical images, people with primary culture. All these had to be struggled with during the following decades.
The following «city stories» (Barr, Allen, Thomson), short-stories by N. Duncan and S. Leacock, farm short-stories with lyrical beginning (R. Knister), psychological short-stories by M. Lowry, memories of D. Pacey, feministic notes of E. Wilson, humorous short-stories by M. Richler, symbolic sketches of P. Page, sentimental sea short-stories by E. Buckler proclaimed the problems of civilization and nature collision. They are united by their problem of a man and nature relations and «the unknown» which can be seen on the background of severe Canadian nature. The world of animals and plants in some respect is embodied in every of these books. All these literary phenomena created at different time are connected by a single topic for Canadian literature - the theme of nature. It proved its stability and longevity during the whole history of the Canadian literature development. From generation to generation Canadian writers tried to find the ways of create a structure for this short-story genre. This process is still in progress and the form of Canadian «story» is still being changed.

Ernest Seton-Thompson is a great Canadian animal story writer of the end of XIXth - the first half of the XX century. During his life he tried to remember people that only the connection with the nature can become a source of joy and understanding 
of the life's value for them. His books opened the contemporaries unknown world in which animals became close to people.

Describing the animals' behaviour E.SetonThompson separates it from fairy-tails. It is important for him a real geographical surrounding which forms characters of his four-legged and feathered friends (Chernyavskaya, 1982, 239). He mentions natural surrounding peculiarities, looks at the world with artist's eyes. Nature in his stories becomes a living creature, a certain personage which is often determines the development of the plot. He saw the beauty of nature everywhere and it gave the feeling of bowing at its wisdom.

In animal stories by E.Seton- Thompson a certain concept of existence is given; it gives a chance to speak about writher's belonging to neoromantic literature.

In his stories animals are living creatures, close to people. Animals in his stories are personified - they love and hate, cry and laugh like people. They are real beasts and birds which live in their world which secrets the writer wanted to understand. He characterizes in an artistic way «psychology» of their personages, arising reader's interest to their fate.

Story «Arnaux, the Chronicle of a Housing Pigeon» is a story about such animal world representatives. In the given article we will try to give a comparative analysis of the story and its translation.

The translators started to translate Ernest Seton-Thompson's books in Russia in 1910.
Among these translations a special attention should be paid to M. K. Chukovsky's one.

Unfortunately, still there is no Ukrainian translation of short-story «Arnaux, the Chronicle of a Housing Pigeon». Russian translation which became a part of collection «Animal Heroes», 1901 was done by M.K.Chukovsky, who strived to preserve maximum of artistic and plot peculiarity of the original. Actions in the Russian variant take place at the same sequence of ideas where all the events of the plot and composition, artistic side of the original were preserved. The translator artistically translated the story, striving to follow the original.

The main aim of the translation is to achieve adequacy. Adequate translation is done on the level necessary and enough to reflect unchangeable content with the following a certain background of expression, in other words, language norms which the text is translated into. The main task of the translator is to achieve adequacy - to use translation techniques professionally to reflect all the information of the original text with the following of all the target language norms as accurate as it is possible.

Transformation is a basis of the most of translation techniques. It lies in the change of formal (lexical and grammatical 
transformations) or semantic (semantic transformations) of the source language components with the preserving of information, necessary for this transformation.

Comparison of the translation of the story «Arnaux, the chronicle of a Housing Pigeon» with the original demonstrates that to transfer the content M.K. Chukovsky widely uses this technique.

The main kind of transformation which is used by the translator at the process of translation is grammar transformations which lie in the reconstruction of the sentence structure in the accordance with the norms of the target language.

The translator often uses sentence division - a type of translation at which syntactic structure of the sentence in the original is performed as two predicative structures of the translation language: «The mild smell of the well-kept stalls was lost in the sweet odor of hay, as we mounted a ladder and entered the long garret» (Seton-Thompson, 1901, 73) («Слабый запах чисто содержимых денников терялся в нежном аромате сена. Поднявшись по лестнице, мы очутились на длинном чердаке») (Seton-Thompson, 2015).

M.K.Chukovsky avoids overloading of the sentence with the information and at the same time underlined the necessity of every component of the narration: «There is no creature with finer sense of locality and direction than a good Homer, and the only visible proofs of it are the great bulge on each side of the head over the ears, and the superb wings» (Seton-Thompson, 1901, 75) $(« \mathrm{Hет}$ на свете существа, обладающего более тонким чувством направления, чем исправный возвратный голубь. Такого голубя всегда можно узнать по большим выпуклостям над ушами и по мощным крыльям») (11).

In the given example a complex sentence is changes into two simple ones and gives a possibility to stress a reader's attention to the detailed description of the main character.

An opposite type of sentence division which can be found in the translation text is sentence unity - a creation of one complex sentence from some simple ones: «One day a carriage drove up to the stable; a white-haired gentleman got out, climbed the dusty stairs, and sat all morning in the loft with Billy. Peering from his gold-rimmed glasses, first at a lot of papers, next across the roofs of the city, waiting, watching, for what?» (Seton-Thompson, 1901, 87) («Однажды к конюшне подкатила карета; из нее вышел седоволосый господин, вскарабкался по пыльной лестнице на голубятню и все утро просидел вместе с Билли, поглядывая сквозь золотые очки то на кучу бумаг, то поверх городских крыш, высматривая и дожидаясь чего?»- Seton-Thompson, 2015).

The connection between these sentences is so tight that their formal unity 
is dictated by the construction of the Russian phrase. More over, the order of language elements changes in the translation that is dictated by grammar rules of the syntax of Russian as for actual division of the sentence when subordinate elements are situated at the beginning of the sentence: «That month he made two new records. He brought a message ten miles in eight minutes, and he came from Boston in four hours» (SetonThompson, 1901, 93) («В этот месяц он установил два новых рекорда: он принес письмо за десять миль в восемь минут и перелетел из Бостона в Нью-Йорк за четыре часа» (11)). Thanks to the device of sentence combination is more tightly accepted as a connection between them.

The translator gives the content to the original with the help of grammatical change as well - a transformation of the grammar part of in the original text by the target language unit with another grammatical meaning: «I shall never forget the sensations of that day» (Seton-Thompson, 1901, 76) («Никогда не забуду, что я пережил в этот день» - Seton-Thompson, 2015); «Some were weak...» (Seton-Thompson, 1901, 77). («Некоторые ослабели...» (11)); «...when with whistle of wings...» (Seton-Thompson, 1901, 88) («...свистя крыльями...» - Seton-Thompson, 2015); «...a class of miscreants who think...»(Seton-Thompson, 1901, 88) («...немало негодяев, считающих...» - Seton-Thompson, 2015).
An appropriate change of the noun «the sensations» by the verb «пережил», subjective predicate construction «were weak» by the verb «ослабели», a noun «whistle» by the verb «остыла» and verb «think» by the participle «считающих» was done for the sake of grammar peculiarities of the target language дотримування and to preserve logical meaning of words.

Comparing the original text with the text of translation one can admit that grammatical transformations of the change are accomplished with the device of the change of the sentence components: «...from the nest where he was hatched...» (Seton-Thompson, 1901, 78) («...потому что он родился в угловом гнезде...»(Seton-Thompson, 2015); «The distance from home, of the start, was "jumped"...» (Seton-Thompson, 1901, 79) («Расстояние с каждым днем увеличивалось...» (Seton-Thompson, 2015)); "... he was thrown into the air ...» (Seton-Thompson, 1901, 82) («Старбек взвился в воздух...» (Seton-Thompson, 2015)); «...the wonderful speed was diminished...» (Seton-Thompson, 1901, 103) («...чудесная скорость теперь уменьшалась...» (Seton-Thompson, 2015)).

In the given cases the change of English passive construction into Russian 
active one takes place. In such a situation English subject corresponds to Russian complement and the word which corresponds to English complement with by becomes a subject.

Sentences «We passed through the side door of a big stable» (Seton-Thompson, 1901, 73), «The fast express was steaming down the valley» (Seton-Thompson, 2015) are translated with the help of putting the adverbial modifier of place at the beginning of the sentence: «Через боковую дверь мы вошли в конюшню», «Внизу, в долине, дымил курьерский поезд».

Such changes are explained by the difference of words order and their functional peculiarities in English and Russian as well as the differences in perception of the actual division of the sentence. Thus, in Russian sentence communicatively important components which carry the new information (the rheme) are put, as a rule, at the end of the sentence. In English sentence the rheme can be embodied by different means which do not demand putting of necessary and the most important information at the end of the phrase.

Dissatisfaction in the structure of different languages lead to the difficulties connected with preserving and transmitting the meaning of words during the translation by the words of different language. Word as a lexical unit is a part of the language system. Semantic structure of a word is a unique for every concrete language. That is why it cans not be preserved in lexical systems of a foreign language and the target language. Thus the translator uses lexical transformations.

In the process of translation many situations occur when lexis of the translation language is more concrete than the same lexical units in English. That is why the device of concretization becomes so popular; its essence lies in the change of words which on the basis of the original language have a rather wide meaning comparing with a word with a more concrete meaning: «This was the home of a famous lot of birds...» (Seton-Thompson, 1901, 73) (« В этой голубятне жили знаменитые птицы...» (Seton-Thompson, 2015)); "A moment later he had the roll in his hand ...»(Seton-Thompson, 1901, 73) (« Через минуту он держал в руке записку ...» (Seton-Thompson, 2015)).

It is seen that the translator has chosen correctly meanings for words «Was», «home» and «have», as in the given context it is necessary to give a more concrete meaning with the help of words «жить», «голубятня» instead of neutral meaning «быть», «дом» and «иметь».

In the following example of the concretization device use for the verb «to go» gives a change to omit informational uncertainty and to demonstrate correctly the content of the sentence: «High in the valleys he went...» (Seton-Thompson, 
1901, 100) «Высоко над долинами он летел ...» (Seton-Thompson, 2015); «These Pigeons are not of any special color ...» (Seton-Thompson, 1901, 75) «Эти голуби не отличаются особой окраской...»(Seton-Thompson, 2015)).

The choice of a concrete meaning for words «be» and «color» is correct here in accordance with the context and general atmosphere of the narration.

A total opposite to concretization is generalization. As English words have a more abstract meaning comparing with the same words from Russian, in the process of translation from English into Russian generalization is used far less that concretization but we cannot omit it at all: «The original fifty birds dwindled to twenty...» (Seton-Thompson, 1901, 79) («Из пятидесяти птиц осталось всего двадцать...» (SetonThompson, 2015)); «They wore no uniform...» (Seton-Thompson, 1901, 79)); «У них не было определенной масти...» (Seton-Thompson, 2015). The translator generalizes notions «dwindle to» and «wear» and changes them into more general words «оставаться» and «быть» which helps to percept the text better. Apart from generalization in the sentence, «They wore no uniform» the meaning of a word «uniform» is more concrete and is changed with the word «масть» which helps to reflex the original text much better.

To reflect the hues of the original text $\mathrm{M}$. K. Chukovsky uses antonymic translation: «He had not much to distinguish him when at rest...»
(Seton-Thompson, 1901, 79) («Он мало отличался от других...» (SetonThompson, 2015)); «Many a noble Homer, speeding with a life or death message...» (Seton-Thompson, 1901, 88) («Не один благородный гонец, летевший с вестью о жизни или смерти...» (SetonThompson, 2015); «At first Arnaux did nothing all day but walk...» (SetonThompson, 1901, 96) «Сперва Арно только и делал, что шагал по целым дням...»(Seton-Thompson, 2015)); «A dark stain appeared on his bosom, but Arnaux kept on...» (Seton-Thompson, 1901, 103) «На груди расплылось темное пятно, но Арно не сдавался...» (SetonThompson, 2015)).

The given examples demonstrate that thanks to this device the translator had a chance to reflect the sense and stylistic meanings of words more thoroughly.

In the process of translation from English some situations occur when wordfor-word translation leads to a grammatically correct expression but it does not correspond the language of translation. Then the translator can use such a device as modulation (semantic development) which lies in the change of a unit being translated into contextual word or word combinations which are connected is it logically: «The old man turned deathly pale, fumbled it open, then his color came 
back...» (Seton-Thompson, 1901, 88) «Старик смертельно побледнел, с трудом развернул ее, и лицо его оживилось...» (Seton-Thompson, 2015); «His beak and feet were small, as became his blood...(Seton-Thompson, 1901, 93) («Клюв и ноги его были малы, как у всякого хорошего почтового голубя...(Seton-Thompson, 2015)).

Expressions «his color came back» and «as became his blood» cannot be translated into Russian using the equivalent; for this it is necessary to change them with the help of the adequate meaning, clear to the reader. That is why M. Chykovsky uses expressions which help to understand the sense meant by the author at once.

In the process of translation lexical transformations of addition can also be used: «You hardly see them till they're in...» (SetonThompson, 1901, 76) («Едва успеешь их заметить, как они уже влетят в голубятню...» (Seton-Thompson, 2015)); «The flash of white, the rush of pinions...» (Seton-Thompson, 1901, 76), («Появление белого облачка, шелест крыльев...» (Seton-Thompson, 2015)) as well as ommitions: «The hardest of all work is over the sea» (Seton-Thompson, 1901, 81) («Труднее всего перелететь через море...» (SetonThompson, 2015)); «Although there were plenty of witnesses...» (Seton-Thompson, 1901, 75) («Несмотря на множество свидетелей» (Seton-Thompson, 2015)).

To sum it up, we would like to mention that having analyzed the original short-story («Arnaux, the chronicle of a Housing Pigeon» by E. Seton-Thompson and its translation in his works K.Chukovsky does not add unnecessary details to the original text preserving its content, the system of images and artistic style of the author. Some differences between the original text and the text of translation do not influence the general perception of the text. That is why such a translation can be called an adequate one because reflecting the content and the form of the original by means of Russian he demonstrates the author's idea to influence the reader calling for his reaction to the story. 


\section{References}

Gachechiladze, 1965 - Гачечиладзе Г. Реалистический перевод и задачи его теории (Вводная лекция к курсу истории и теории художественного перевода) / Г. Гачечиладзе //Мастерство перевода. - М.: Советский писатель, 1965. - С. 241-251.

Rebri, 2012 - Ребрій О.В. Сучасні концепції творчості у перекладі: (монографія) (Текст) /О. В. Ребрій. - Х.: ХНУ імені В. Н. Каразіна, 2012. - 376 с.

Koptilov, 1972 - Коптілов В. Першотвір і переклад (Роздуми і спостереження) (Текст) / В. Коптілов. - Київ: Дніпро, 1972. - 215 с.

Novikova, 1982 - Новикова М. Перекладач і класика (про форми і межі перекладацької інтерпретації) (Текст) / М. Новикова // «Хай слово мовлено інакше...»: статті 3 теорії, критики та історії худож. перекладу / (упоряд. В. Коптілов). - Київ, Дніпро, 1982.- C. $40-5$.

Sukhenko, 2002 - Сухенко И.Н. Национальные варианты канадского анималистического рассказа конца XIX - начала XX вв.//Дніпропетровський університет.

Вісник. Літературознавство. Журналістика. - Дніпропетровськ: ДГУ, 2002. - Вип. 5. - С. 107-111.

Hammill, 2007 - Faye Hammill. Canadian Literature. Edinburgh: Edinburgh University Press, 2007. -220 p.

The Canadian Imagination..., 1977 - The Canadian Imagination Dimensions of a Literary Culture. Cambridge: Harvard University Press, 1977. —265 p.

Korotich, 1980 - Коротич В. Голоса Канады: Путевые заметки// Иностранная литература. - 1980.- №8. - С. 212-223.

Chernyavskaya, 1982 - Зарубежная детская литература: Учебник для институтов культуры (Текст)/ Сост. И.С. Чернявская. - 2-е изд. - М.: Просвещение, 1982. - 559 с.

Seton-Thompson, 1901 - Ernest Seton-Thompson. Animal Heroes. New-York: The Century Co, 1901. $-345 \mathrm{p}$.

Seton-Thompson, 2015 - Эрнест Сетон-Томпсон Арно (електронний ресурс): доступно 3: http://www.serann.ru/text/arno-9625 